\title{
Solid Waste Management in Island Communities: Case Study in Arjasa District, Kangean Island
}

\author{
Shabaria Mahsuna Rahman ${ }^{1 *}$ and Arseto Yekti Bagastyo ${ }^{2 \dagger}$ \\ ${ }^{1}$ Postgraduate Study of Environmental Engineering, Department of Environmental Engineering, Institut \\ Teknologi Sepuluh Nopember, Surabaya 60111, Indonesia \\ ${ }^{2}$ Department of Environmental Engineering, Institut Teknologi Sepuluh Nopember, Surabaya 60111, \\ Indonesia
}

\begin{abstract}
Arjasa is one of Districts located in Kangean Island Madura that has been densely populated by more than 86.000 people. However, the solid waste management system fulfilling the Government Regulation (PP) $81 / 2012$ remains a challenge in the area. The local government has been struggling to provide adequate infrastructure due to their limited resources, let alone local communities' participation in the waste management. Therefore, this study aims to determine a best-practice solid waste management system in the district. The assessment includes technical aspect (SNI 190394-1994), and in-depth survey on organizational concept and social participation. Waste sampling was done in 5 out of 19 villages in the district, i.e., Arjasa, Angon-angon, Kalisanka, Paseraman, and Pabian. The result shows that 35,282 ton/day of waste was generated in Arjasa District. The waste component was consisted of $62.70 \%, 15.17 \%, 10.10 \%, 0.27 \%$, $1.03 \%, 0.47 \%, 0.37 \%, 1.27 \%, 0.37 \%, 1.5 \%, 0.37 \%$, and $6.4 \%$ identified as compostable wastes (food wastes and garden wastes), plastics, papers/cardboards, wood, fabrics, cans, glass, rubber, e-waste, diapers, styrofoam, and residues, respectively. Based on its possible reduction and separation/processing method by the communities, the waste collection/transfer and transport system were then designed. The proper organizational structure involving the government and the communities was also determined.
\end{abstract}

\footnotetext{
* Corresponding author: shabariamr05@gmail.com
} 


\section{Introduction}

Solid waste management issues are the biggest challenge for a small island in developing countries. Among several issues faced by a small island in developing countries over the years, increasing waste generation is becoming one of the major problems. In addition, the problems of land scarcity, lack of economic resources, and expertise in the field of waste management considerably reduce the waste management potentials in small islands [1]. Arjasa is one of the Districts located in Kangean Island Madura that has an area of 247, 97 $\mathrm{km} 2$. Arjasa District consists of 19 villages and has been densely populated by more than 86.000 people [2]. Arjasa District is one of those small islands that currently struggling to provide proper waste management according to Government Regulation (PP) 81/2012. Currently, illegal dumping and burning prevail in Arjasa District communities.

Research in waste management has been conducted on a small island exactly in Pramuka Island. The result of the study reveals that $75 \%$ of the communities dumped their waste into the backfill, $15 \%$ into the disposal site, $5 \%$ into the sea, and 5\% recycled their waste. The Pramuka island community argued that the reason for not disposing of the waste at the disposal site was the distance and the facilities not properly provided. The facilities for processing and final disposal of waste available on Pramuka Island are incinerators and landfills, however, incinerators are not used properly. Several waste management programs are suggested for Pramuka islands such as Waste Awareness Program, Waste Sorting Program, and the Collaboration Enhancement program between stakeholders to increase residents' interest in using plastics to become handicrafts [3].

Other research about waste management in the small island was done in Bunaken Island, the characteristic of waste produced in Alung Belua Village are $21 \%$ organic waste, $63 \%$ inorganic waste, and $10 \%$ other waste. The waste produced in Bunaken Village is $50 \%$ inorganic waste, $45 \%$ organic waste, and $5 \%$ other waste. The waste processing facilities provided by the Manado city government for Bunaken Island are plastic chopping machines (Bunaken Village) and composting facilities (Alung Banua Village). However, even though the local municipal government has provided waste processing facilities, the culture of community behavior on Bunaken Island in managing household waste generated is still carried out by burning waste in open spaces or illegal dumping [4].

Waste management is a system consisting of several components aspect, technical operational aspect, the institutional aspect, and the community aspect. These aspects are interrelated and must be considered to create an effective waste management system [5]. Operational technical aspects consist of reduction and handling activities. Waste reduction is carried out by limiting, reusing, and recycling. Waste handling starts from the storage, collection, processing, and disposal of solid waste. Implementation of waste management requires an institution that is responsible for running the waste management. Waste management is not only the responsibility of the government but also the support of the communities is required. If the government considers implementing policies and providing proper waste management facilities to solve the waste problem, it is important to know the communities' desire to participate. Therefore, this study aims to determine a best-practice solid waste management system in Arjasa District, organizational structure involving the government and the communities' willingness to participate was also determined.

\section{Material and Method}




\subsection{Study Area}

This study took place in Arjasa District, one of the Districts located in Kangean Island. Kangean is one of the archipelago areas in Sumenep Regency which is located eastern part of Madura Island. Astronomically, Kangean is at coordinated 5\%4'39"LU dan 114 $36^{\prime} 5^{\prime \prime} \mathrm{BT}$. The boundaries of the area are as follows:
- North : Boreno Sea
- East : Bali Sea
- South : Bali Sea
- West : Madura Island

The characteristic of the local climate tends to be dry (average rainfall $2000 \mathrm{~mm} / \mathrm{year}$ ). Based on the analysis of the rainfall, it appears that the rainfall climate in the Kagean Island cluster is tropical monsoonal, that is, the rainy or wet season falls from the end of October to March, while the dry season (dry) falls from April and May. During the dry season, the temperature ranges from $31^{\circ} \mathrm{C}-32^{\circ} \mathrm{C}$. While the rainy season the average temperature is $28^{\circ} \mathrm{C}$. The number of rainy days in Ajasa District is 126 days with a rainfall of $1712 \mathrm{~mm}$. Kangean Island has an area of $648,56 \mathrm{~km} 2$ divided into two districts i.e Arjasa District and Kangayan District. Arjasa District has an area of $241,97 \mathrm{~km} 2$ or $9,67 \%$ of the total area of Sumenep Regency. Arjasa District consists of 19 villages and has population of 86.655 people. For the details, the location of the study can be seen in Figure 1.

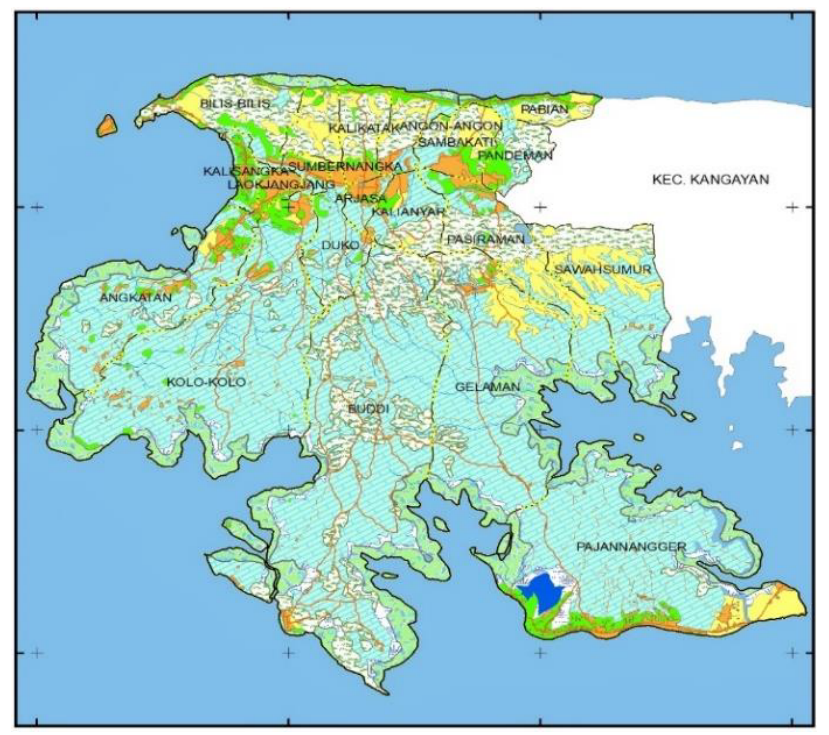

Fig.1. Study Area.

\subsection{Population and Waste Sample}

The population of this study is all households from the study area. Based on BPS data 2019 that the population in the study area was 86.655 people. The number of samples used in this study follows the guidelines in SNI 19-3964-1994, based on the calculation results, the number of research samples is 30 households. Then in the sample selection of households selected by stratified random sampling from the group of permanent houses as many as 1 household, semi-permanent houses as many as 24 households, and non-permanent houses as many as 4 households. The determination number of the sample was then followed by the 
determination of the sample area. The sample area was determined purposively based on the level of population density in 5 villages out of 19. Arjasa, Angon-Angon, Kalisangka village as areas with high population density, while Pabian and Paseraman villages as areas with low population density.

Tabel 1. Population Density of Sample Area.

\begin{tabular}{|c|l|c|c|c|}
\hline No & \multicolumn{1}{|c|}{ Villages } & Population & Area (km2) & Population density \\
\hline 1 & Arjasa & 4.570 & 1,47 & 3.109 \\
\hline 2 & Angon-Angon & 4.033 & 3,8 & 1.061 \\
\hline 3 & Kalisangka & 4.377 & 2,07 & 2.114 \\
\hline 4 & Paseraman & 3.819 & 11,61 & 329 \\
\hline 5 & Pabian & 458 & 2,91 & 458 \\
\hline
\end{tabular}

\subsection{Research Instrument}

To obtain the waste generation and composition data, measurements were carried out following the standards of SNI 19-3964-1994. Sampling was carried out for 4 consecutive days (18 March - 21 March 2021) from the selected household sample. The research equipment used to measure waste generation and composition consists of a measuring box with dimension $20 \mathrm{~cm} \times 20 \mathrm{~cm}$ x $100 \mathrm{~cm}$ and $50 \mathrm{~cm} \times 100 \mathrm{~cm} \times 100 \mathrm{~cm}$, a $5 \mathrm{~kg}$ capacity scale, and $100 \mathrm{~kg}$ capacity scale, a $60 \mathrm{~L}$ plastic bag, masks, gloves, and writing tools.

The steps of measuring waste generation, as follow [6]:

- Waste generation

Distributed $60 \mathrm{~L}$ plastic bags to 30 selected households (each household gets 4 plastic bags) a day before the measurement.

Collect the $60 \mathrm{~L}$ plastic bags from the households.

Measure the weight of measuring box $(20 \times 20 \times 100) \mathrm{cm}$.

Put the waste from each household in the measuring box and stomp the measuring. box three times by lifting it as high as $20 \mathrm{~cm}$.

Measure the weight and volume of waste.

- Waste composition

Measure the weight of the measuring box $(50 \mathrm{~cm} \times 100 \mathrm{~cm} \times 100 \mathrm{~cm})$.

Put and mix all of the samples in the measuring box and stomp the measuring box three times by lifting it as high as $20 \mathrm{~cm}$.

Sort the waste according to the type of waste.

Measure to get waste composition (\%). 


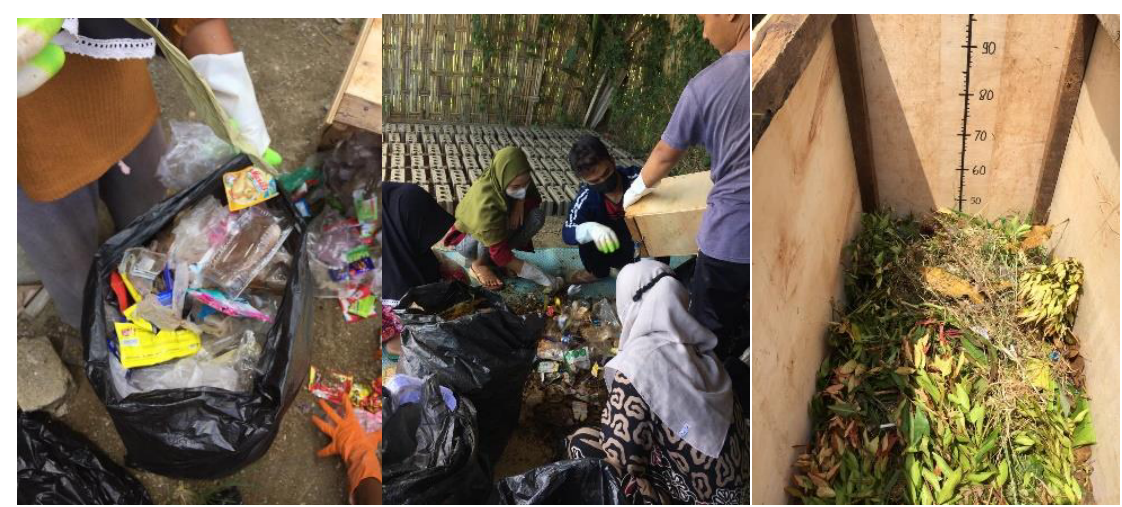

Fig. 2. Sampling Activities.

\section{Result and Discussion}

\subsection{Existing Condition of Solid Waste Management at Arjasa District}

Arjasa District has never implemented a solid waste management system. Population growth and increased human activity further lead to an increase in waste generation, therefore waste management should be done as soon as possible. Arjasa District communities manage the waste they produced daily by making illegal dumping in an unused area, throwing the garbage into drains, disposing of the waste in a coastal area, or burning the trash.
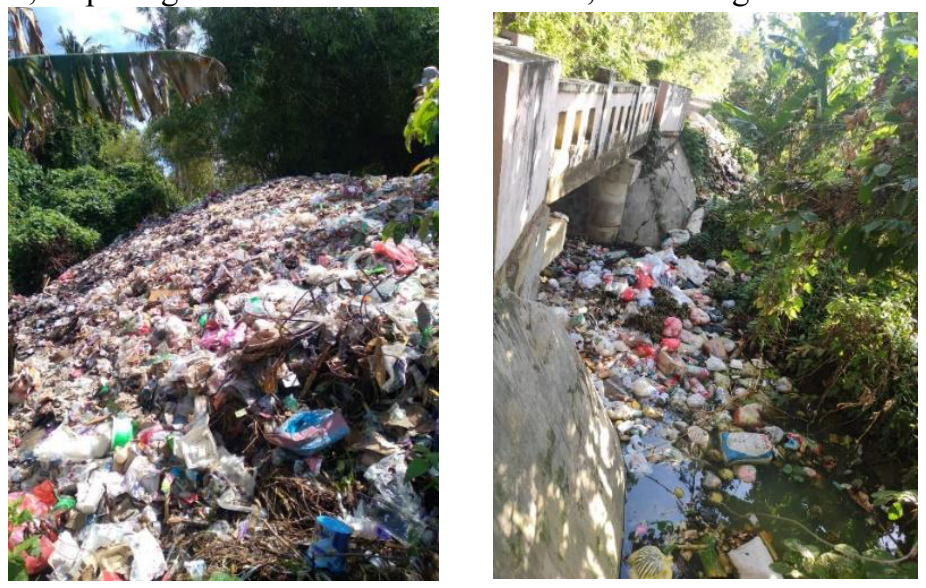

Fig. 3. Current Situation of Waste Disposal at Arjasa District.

\subsection{Waste Generation and Composition at Arjasa District}

Table 2. Waste Generation at Arjasa District.

\begin{tabular}{|c|l|c|c|}
\hline No & \multicolumn{1}{|c|}{ Type of House } & $\begin{array}{c}\text { Massa } \\
(\mathbf{k g} / \text { person/day) }\end{array}$ & $\begin{array}{c}\text { Volume } \\
(\mathbf{m 3} / \mathbf{p e r s o n} / \mathbf{d a y})\end{array}$ \\
\hline 1 & Permanent house & 0,81 & 0,0056 \\
\hline 2 & Semi permanent houses & 0,50 & 0,0037 \\
\hline 3 & Non permanent houses & 0,24 & 0,0024 \\
\hline
\end{tabular}


Based on Table 1 waste generation of permanent house is $0,81 \mathrm{~kg} /$ person/day or 0,0056 $\mathrm{m} 3 /$ person/day, semi-permanent houses is $0,50 \mathrm{~kg} /$ person/day or $0,0037 \mathrm{~m} 3 /$ person/day and non permanent houses is $0,24 \mathrm{~kg} /$ person/day or $0,0024 \mathrm{~m} 3 /$ person/day. The difference in the result can be influenced by several factors such as living standards, technology, believes and culture applied waste management regulations, and economic conditions [7].

With this waste generation, data can be an input to calculate the needs of waste management facilities in Arjasa District such as the needs of volume storage, the needs of temporary shelter and recycling area, the need for transportation for collection, and the needs of landfill area. When it comes to the type of processing and transformation process in the recycling area composition data is needed.

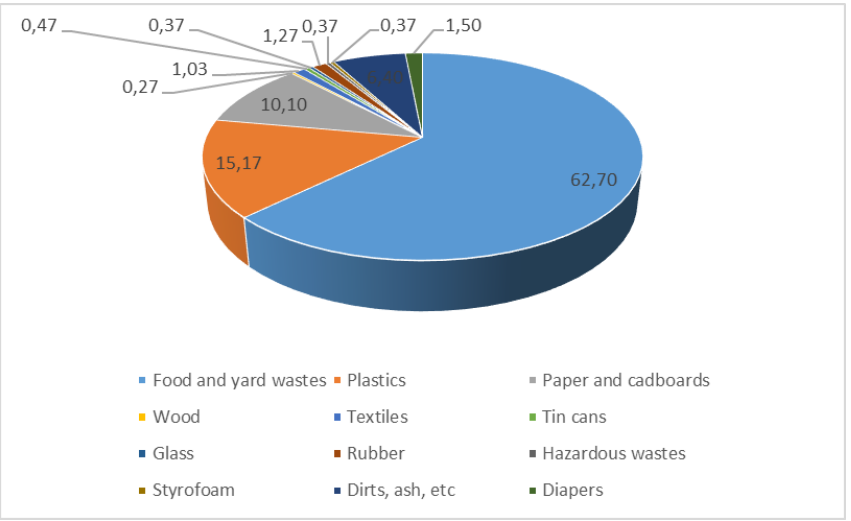

Fig. 4. Waste Composition at Arjasa District.

Besides waste generation, the waste composition is an important parameter in the development of proper waste management strategies. From the waste composition data, the recyclability, combustibility, or biodegradability of the waste streams can be identified and these can be subsequently used for designing and implementing appropriate waste management technologies [8]. The result on Figure 4 shows that the waste component was consisted of $62.70 \%, 15.17 \%, 10.10 \%, 0.27 \%, 1.03 \%, 0.47 \%, 0.37 \%, 1.27 \%, 0.37 \%, 1.5 \%$, $0.37 \%$, and $6.4 \%$ identified as compostable wastes (food wastes and garden wastes), plastics, papers/cardboard, wood, fabrics, cans, glass, rubber, e-waste, diapers, styrofoam, and residues, respectively.

\subsection{Design of Solid Waste Managemet At Arjasa District}

\subsubsection{Storage of Solid Waste at The Source}

Storage of waste at the source is the first essential step of solid waste management. Every household, shop, and establishment generates solid waste on day to day basis. The waste should be normally be stored at the source of waste generation till collected for its disposal.

Based on the sampling waste generation, the sample was categorized on the type of residential buildings such as permanent house, semi-permanent house, and non-permanent house. This categorization can affect the density and volume values of the waste. The volume of waste is determined by dividing the weight of the waste bydensity.

Calculate the waste generation (m3/day):

- Permanent house

Mass of waste

$=3,25 \mathrm{~kg} /$ day

Permanent house waste density

$=146,93 \mathrm{~kg} / \mathrm{m}^{3}$ 


$$
\text { Waste volume } \quad \begin{aligned}
=\frac{3,25 \mathrm{~kg} / \text { day }}{146,93 \mathrm{~kg} / \mathrm{m3}} \\
=0,02 \mathrm{~m}^{3} / \text { day }=20 \mathrm{~L} / \text { day }
\end{aligned}
$$

Using the same equation, the waste volume of the semi-permanent house and the nonpermanent house is $15 \mathrm{~L} /$ day and $10 \mathrm{~L} /$ day.

After calculating the waste volume produced per day, then calculate the volume of the required trash can. In this study, waste sorting is carried out from the source so that at the time of processing each type of waste can be maximally utilized to reduce the amount of residue wasted in landfills. The waste containers are determined to be two types organic and inorganic waste. Organic waste containers for food and yard waste, while inorganic waste containers consist of all types of waste produced (except organic waste)

Calculate the volume storage:

- Permanent house

$$
\begin{aligned}
\mathrm{V}_{\text {organic }} & =\mathrm{V}_{\text {foodwaste }}+\mathrm{V}_{\text {yardwaste }} \\
& =62,7 \% \times \text { (waste volume) } \\
& =62,7 \% \times 20 \mathrm{~L} \\
& =12,54 \mathrm{~L} \\
& =\mathrm{V}_{\text {plastick }}+\mathrm{V}_{\text {paperandcupboard }}+\mathrm{V}_{\text {kwood }}+\mathrm{V}_{\text {tin }}+\mathrm{V}_{\text {textile }}+\mathrm{V}_{\text {rubber }}+\mathrm{V}_{\text {glass }}+ \\
& \mathrm{V}_{\text {intyrofoam }}+\mathrm{V}_{\text {diapers }}+\mathrm{V}_{\text {hazardous }} \\
& =37,3 \% \times \text { (waste volume) } \\
& =37,3 \% \times 20 \mathrm{~L} \\
& =7,46 \mathrm{~L}
\end{aligned}
$$

Number of $62,7 \%$ and $37,3 \%$ is the organic and inorganic waste composition.

$$
\begin{aligned}
& \text { * Collection rate }(n) \quad=1 \text { per day } \\
& \text { * Safety factor }\left(\mathrm{S}_{\mathrm{f}}\right) \quad=2 \\
& \text { * Volume of storage }=\mathrm{V} / \mathrm{n} \mathrm{x} \mathrm{S}_{\mathrm{f}} \\
& \text { * Volume of organic storage } \quad=12,54 / 1 \times 2
\end{aligned}
$$

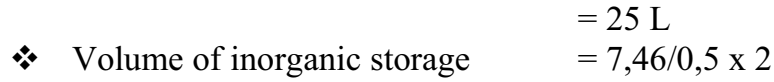

$$
\begin{aligned}
& =15 \mathrm{~L}
\end{aligned}
$$

Use the same equation the storage volume for semi permanent house is $20 \mathrm{~L}$ and $15 \mathrm{~L}$, non permanent house is $15 \mathrm{~L}$ and $10 \mathrm{~L}$.

\subsubsection{Collection of Solid Waste}

Waste collection is an important functional element of the waste management system. The absence of a proper waste collection system completely disrupts the waste management flow and the waste generators resort to illegal unwanted practices like dumping at forbidden sites and backyard burning of wastes. In many small islands, these practices are prevalent and result in severe ecological and health effects due to the release of toxic emissions during burning and the spread of diseases from illegal dumping [8]. Because in Arjasa District the roads in a residential area are a little bit narrow, the waste collection is designed by use vehicle.

Number of vehicle determined as follow:

- Collection schedule; eg: everyday, 3 times per weeks etc

- Volume of vehicle container : $2 \mathrm{~m}^{3}$

- Number of ritation

- $\quad$ Number of vehicle $=\frac{\text { Volume sampah }}{\text { Kapasitas } x \text { Jumlah ritasi }}$ 


\subsubsection{Separation, Processing and Disposal of Solid Waste}

Several technologies can be employed for waste management. These range from recycling, composting, thermochemical process, and ultimate disposal in landfills. Considering the high organic nature of wastes in Arjasa District, composting seems to be the most appropriate technology for managing municipal solid waste in Arjasa District. As for the next highest fraction (recyclables), these can be subjected to recycling or waste-to-energy (WTE) technologies.

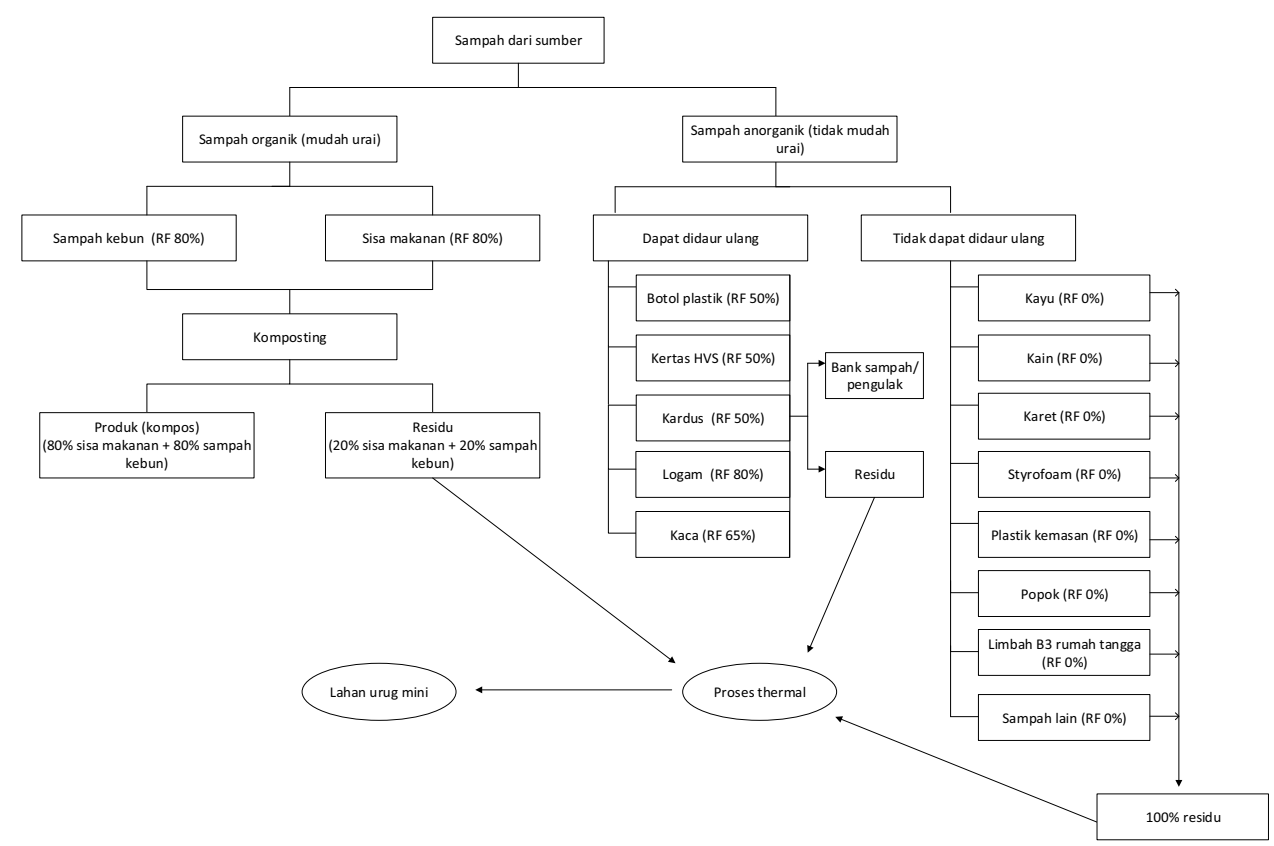

Fig. 7. Flow diagram for the separation processing and disposal of solid waste at Arjasa District.

\section{Conclusion}

The rates of waste Arjasa District is $0,81 \mathrm{~kg} / \mathrm{person} /$ day for permanent house, 0540 $\mathrm{kg} /$ person/day for semi-permanent house, and $0,24 \mathrm{~kg} /$ person/day for non permanent house. Composition of waste was consisted of $62.70 \%, 15.17 \%, 10.10 \%, 0.27 \%, 1.03 \%, 0.47 \%$, $0.37 \%, 1.27 \%, 0.37 \%, 1.5 \%, 0.37 \%$, and $6.4 \%$ identified as compostable wastes (food wastes and garden wastes), plastics, papers/cardboard, wood, fabrics, cans, glass, rubber, e-waste, diapers, styrofoam, and residues, respectively. The waste management system that can be applied in Arjasa District can be started from storage at the source which is divided into types storage, organic waste for food and yard waste, while inorganic waste containers consist of all types of waste produced (except organic waste). Then it was continued with waste collection activities from the source. Waste processing starts with sorting inorganic waste that is suitable for recycling. Organic waste consisting of food and yard waste should be processed into compost using the open windrow composting method. Furthermore, the residue of organic and inorganic waste is processed using thermal technology and then dumped in a mini backfill area. 


\section{References}

1. UNEP. 1999. Waste Management in Small Insland Developing States. Progress in the Implementation of the Programme of Action for the Sustainable Development of Small Island Developing States.

2. Badan Pusat Statistik. Kecamatan Arjasa Dalam Angka. (2019)

3. Nasution, S. R dan Tjahjani, AR. .2019. Analisis Laju Timbulan Sampah Di Pulau Pramuka DKI Jakarta. Jurnal Ilmiah Teknik Industri. Vol. 7 (1) (2019)

4. Manik, R. T. H. K., Makainas, I., Sembel, A. 2016. Sistem Pengelolaan Sampah Di Pulau Bunaken. Program Studi Perencanaan Wilayah dan Kota Universitas Sam Ratulanggi Manado (2016)

5. Kementrian Pekerjaan Umum dan Perumahan Rakyat (PUPR). Tata Cara Penyelenggaraan Sistem Pengelolaan Sampah Di Kawasan Pulau Kecil. (2016)

6. SNI 19-3964-1994 tentang Metode Pengambilan dan Pengukuran Contoh Timbulan dan Komposisi Sampah Perkotaan

7. Keser, S., Duzgun, S., Askoy, A. 2012. Application of Spatial and Non-Spatial data Analysis in Determination of the Factors That Impact Municipal Solid Waste Generation In Turkey. Waste Manage. Vol. 32 (3) (2012)

8. Mohee, R., Mauthoor, S., Bundhoo, Z. M.A., Somaroo, G., Soobhany, N., Gunasee, S. 2015. Current Status of Solid Waste Management In Small Island Developing States : A Review. Waste Management. Vol. 43 (2015) 